\title{
MALE AND FEMALE CLIENTS OF MEN PROVIDING SEXUAL SERVICES: RESEARCH REPORT
}

\author{
RENATA GARDIAN-MIAŁKOWSKA ${ }^{1}$ \\ ${ }^{1}$ Stefan Batory State University in Skierniewice, Batorego 64C, 96-100 Skierniewice, Poland. ORCID: \\ 0000-0002-1063-589X, Email: rmialkowska@pusb.pl
}

\begin{abstract}
The aim of the research was to gain knowledge of who the people using sexual services are, why they do it and what their relationship with men offering paid sex looked like. Results show that the people who used sexual services were both men and women of different ages and with different professional status. The main reasons for using paid sex services were: unsatisfactory sexual contact,; a sense of loneliness and being neglected by the life partner, partner's infertility, heartbreak or betrayal of a partner, problems with finding the right partner, unusual sexual preferences, change of gender and treatment of sex-meetings as a form of entertainment.

KEYWORDS: male prostitution, sexual services, clients, violence
\end{abstract}

\section{INTRODUCTION}

$\mathrm{M}$ ale prostitution is a phenomenon little-known, and recognized as undertaken primarily for money. Male prostitution, both in Poland and worldwide, has not been the subject of comprehensive and systematic research and the results present negative and falsified image referring mainly to young "innocent" boys practicing prostitution on the street. However, not only boys provide such services, and not exclusively on the street. Weitzner (2005: 214) believes that only $10-30 \%$ of people do prostitution on the street ${ }^{1}$. The vast majority of men in the sex-business operate more

\footnotetext{
${ }^{1}$ The best-known places to use sexual services are, among others, 53rd Street in New York, Santa Monica Boulevard in Los Angeles, Piccadilly Circus in London, Polk Street Gulch in San Francisco, The
} 
discreetly and male prostitution is almost always presented as a trade transaction. Marlowe (1997) points out that this transaction is ambiguous, because people who enter into it are not perceived as the exploited and the exploiting.

Nowadays, the phenomenon of male prostitution is experiencing its renaissance. New places are created where anyone can use the services of paid lovers. There are bars, nightclubs (Weitzer 2005), private flats (Kurzępa et al. 2008; Smith \& Grov 2011) and escort agencies (Schifter 1998; Smith \& Grov 2011), there are advertisements in the press and Internet (Smith \& Grov 2011; Kurzępa 2012). Clients can take advantage of the different resources offered (Kurzępa 2012: 300).

When analyzing the phenomenon of prostitution, people using the services of male sex workers should not be overlooked. Clients are both men and women. According to the literature, men who practice prostitution are of homosexual and bisexual orientation. A large group of them are married with children. Some of them are heterosexuals - they and use social services occasionally. Other clients are lonely people who cannot satisfy their sexual and non-sexual needs (Smith \& Grov 2011).

Clients can be divided according to age categories: clients of the same age as male prostitutes; older than sex workers (age difference lower than 10 years); much older clients (10 and more years). This was also confirmed in study by West and De Villiers (1993) which shows that men aged 40-50 constitute 39\%, over $50-33 \%$, and 20-30 - 20\% of clients of male prostitutes. The surveyed clients most often pursued the following sexual services: mutual masturbation, oral and anal sex. Anal sex is offered by $50 \%$ of sex workers, half of which are in active form (Pospiszyl 2008: 237). Customers, especially those looking for services in bars, are called "Johns" or "Tricks." Schifter (1998: 74) indicates one more type of customers who are referred to as "Pagadors". Such clients are usually pederasts who like young boys with hairless skin and a large penis. Sometimes it is also enough that they are exceptionally handsome and have great sexual skills (Schifter 1998: 105). Customers using the services of young boys are convinced that sexual activity with them is safe, because it carries the smallest risk of getting infected with sexually transmitted diseases. Some of their clients are often addicted to perverse sex (Schiffer 1998: 61). Others have problems with their own identity, which affects the sense of self-esteem, their sexuality so buying sexual relations is one of the ways of "self-healing" (Śpila 2006: 94-95). Some clients tend to be intellectually or physically disabled, and thus, cannot enter into "normal” partner and sexual relationships. For some, paying for sexual intercourse is a way to satisfy the desire (Śpila 2006: 94).

In order for the customer to be satisfied with the sexual service he purchases, certain conditions must be met, such as punctuality, communicativeness, discretion and courtesy, as well as adherence to the basic principle that the client is to enjoy sexual pleasure, and the pleasure of a prostitute is only a nice addition (Smith \& Grove 2011: 134). Frequently, homosexual clients are not fully satisfied, because they need more sex and are more aggressive in their behavior. Sadomasochism preferences are often

Drug Store and Rue Saint Anne in Paris, County Routhe 527 in New Jersey, Taksim Square in Istanbul, ZOO Train Station Berlin, while in Poland these are: Park Książęcy, Park Skaryszewski, Pl. 3 Krzyży at Żurawia Street, so-called “Grzybek” or "Avenue of Stars" in Warsaw. 
rejected by male prostitutes, although some clients use abuse and violence (West \& De Villiers 1993).

Customers sometimes create their own websites and assess their level of satisfaction with the services of a particular boy. Their appearance, personality and behavior are evaluated. Other clients pay attention to such features as communication skills and listening skills (Smith \& Grov 2011: 10,70). Clients compare male prostitutes with each other also in terms of prices. It often happens that escorts themselves contact a dissatisfied customer in order to mitigate the bad impression, because they realize that a bad opinion can spoil their reputation and they might earn nothing (Smith \& Grov 2011: 10). Customers buy people who will listen to them, talk in a designated way. They control the course of the meeting, which could not be possible in a non-commercial interaction with a man (Smith \& Grov 2011: 10). However, before the boys are sent to the client, they are thoroughly instructed and informed about what the client likes, what expectations they have about the appearance or sexual preference, and what they can expect from that client. The boy receives tips on how to develop relationship with the client while maintaining dignity and security, and learns how to deal with the negative effects of the work. In escort agencies, experienced escorts are combined with new employees, who learn to work with clients in this way (Smith \& Grov 2011: 63). First of all, they learn to set boundaries that are necessary. Being careful when meeting with a client has a significant impact on the quality of experience with the client. The more enjoyable the experience, the more the customers will feel the pleasure of the meeting (Smith \& Grov 2011: 68). Most clients contact the agency one or two days in advance. Therefore, the agency manager can determine which escorts he will send.. Agency asks the client about his/her preferences regarding appearance (eg, hair color, size of the penis, body structure, etc.) and sexual preferences, in order to meet their expectations in the most optimal way. The client also sets the time and place. The service fee is charged in advance at the beginning of the meeting. Escort, although he is ordered for one hour, in fact spends more time with the client. Escort could end the meeting by leading the client to orgasm and leave, but the client is satisfied with the meeting which satisfies the non-sexual needs, too (Smith \& Grov 2011: 140). In bed one can release anger or confirm their masculinity or femininity or heal their emotional wounds (Hajcak \& Garwood 2001: 17). Customers often hire escorts with whom they had previously established a "positive relationship" and believed that they devoted their time to meet their needs (Smith \& Grov 2011: 140). Escorts can also be ordered to stay longer or travel with the customer, eg on holiday trips. This customer is responsible in such cases for covering all costs. Also, in this case, escorts are forced to provide their real personal details as well as their dates of birth. Escorts always inform their clients that sexual intercourse requires using a condom. Most of them are open to oral sex, they often put a limit on anal sex. However, some men who provide sexual services decide to have anal sex when they know the client longer, trust him, and feel comfortable with him (Smith \& Grov 2011: 145-146).

As I mentioned earlier, male sexual services are also used by women, which may come as a surprise, because at the end of the last century there was a widespread belief in our society that women are not interested in the sexual sphere, but mainly in love, a 
sense of security and a happy and stable relationship (Orliński 2013: 38). But there are women who use such services. And there is no age limit here (Orliński 2013: 38-39).

Some female clients are tired of suppressing their sexual needs. Their life partners do not usually realize them or show a certain "disability" in intimate matters. Despite disappointment with the sexual lives with their partners, women do not want to leave them. Therefore, one can say that the sexual desires of both male and female clients are unmet and this is one of the reasons for using the services of male sex workers. There are also female clients who are inhibited, fearful, inexperienced, those who do not want to disappoint their future sexual partners, and decide to first gain sexual experience with a male sex worker. There are also women who are excited about the fact of paying a man for sex, which is more important than just taking pleasure in a sexual act (Imieliński 1990: 135-136). This type of female client Andy Collins (2004: 212) described as "women intoxicated with power." It is a group of women who know what they want; they pay and require. Collins also discusses older women, lonely women and women of menopausal age. The latter is the type of women who, when young, did not allow themselves to realize their crazy ideas and fantasies. Currently, some women are tired of looking for love that may turn out to be a disappointment. It is much easier to hire someone for an hour or an evening. The female clients are usually wealthy women and in some way unhappy. The next group are women whose husbands leave for long business trips (Imieliński 1990: 135).

In 1969, in the magazine "Jasmin”, the ads of escorts agencies were published. People working in these agencies later admitted that some women, just like men using paid lovers, ordered their services over the phone. Some of them asked about the details of the physical appearance, the size of the genital organs, as well as the skills and sexual potential. In Italy, Donne e Qualità di Vita carried conducted internet surveys among 1,500 women in the 18-50 age group. These studies show that $19 \%$ of women paid for sexual services, while every fourth considered such a possibility. The largest group of these women were aged 30-40 (38\%), another group aged 40-50 (25\%). They were mostly living in large urban agglomerations (37\%). Regarding their marital status: $35 \%$ were unmarried, $27 \%$ were divorced and $21 \%$ were married. Most of them were professionally active: $23 \%$ were businesswomen, $19 \%$ women were managers, $14 \%$ were female artists and journalists, $13 \%$ were clerks, $8 \%$ women worked part-time and $5 \%$ were housewives. The examined women indicated the following reasons for using sex services: seeking satisfactory sex (22\%), emotional closeness (18\%), satisfying their sexual needs (16\%) and entertainment (9\%) (cf. Gardian-Miałkowska 2016: $52)$.

The female clients are young, middle-aged and older women. They are single women, married divorcees and widows. They do not only expect to have their sexual desires fulfilled, but they also want to feel adored. Some of them are women who are successful in their professional lives, while others are bored and in the absence of their husbands look for consolation (Gardian-Miałkowska 2012: 300). For most female clients, sexual intercourse is a complement to intimate, cultural meetings that are filled with long conversations, eating good meal and savoring a good wine. If it comes to sex, it will depend on women's preferences (Rot 2009). 
The men offering paid sex, have developed abilities to talk properly with such women. It is not recommended to discuss topics such as religion or politics that would somehow force the female client to present an opinion. The female client is not looking for debates or sophisticated conversations during paid meetings. The only thing that is expected is frivolous conversation and flirting. The most secure topic of conversations are various types of gossips (Imieliński 1990: 134-136).

\section{RESEARCH PROBLEM}

The sexual services provided by men worldwide have not yet been subject to comprehensive research and should be made the matter of special social significance and systematic interest by scientists and social rehabilitation pedagogy activists.

Therefore, the subject of the analysis in this article will be the answer to the following questions: Who are the people using paid sexual services? What are the reasons for using paid sex services?

Sociographic features of this group and the properties related to their sexual lives have been the subjects of detailed analysis.

\section{ETHICAL ISSUES}

The presented study takes into account the ethical principles of conducting the scientific research. Prior to the study, potential respondents were informed about its purpose and scope. The anonymity and modification of respondents' personal data were secured. The research was carried out as part of a research project ${ }^{2}$, which received positive evaluation of the Research Ethics Committee of the Academy of Special Education Maria Grzegorzewska.

\section{RESEARCH ORGANIZATION}

The research was carried out from January 2012 to June 2013, while one interview was conducted in June 2014. The study covered 27 men providing sexual services. They were users of such websites as: www.gejowo.pl; www.sponsoraszukam.pl; www.eamore.com.pl; www.sponosrujmnie.pl; as well as two non-profit organizations (Social Committee on AIDS and Lambda Warsaw).

For the information and time given, men received previously negotiated financial gratification, only if they participated in the full interview. Six men gave up the fee.

The interviews took place in cafes and restaurants; three times in the respondents' car, two in the shopping center, another three in the Social AIDS Committee and two at the Lambda-Warsaw residence. The research was carried out in the respondents' cities (Warsaw, Radom, Katowice, Żywiec, Poznań, Cracow and Łódź). The conversation usually lasted from 45 minutes to 95 minutes. The average talk time was 60 minutes.

\footnotetext{
${ }^{2}$ Project entitled "Psychosocial conditioning of male prostitution". Project manager: Renata Gardian-Miałkowska. The project was implemented in the period July 2012-June 2013, at the Academy of Special Education Maria Grzegorzewska BTSM 9/2012.
} 
The interviews were recorded with the consent of the respondents, one man refused to record the interview. Then transcriptions were made and analyzed. Interviews were conducted in Polish, and the quoted fragments were translated into English by the author of the article.

\section{RESEARCH SAMPLE}

In the study group there were 27 men, including 6 people defining their sexual orientation as homosexual and 21 people as heterosexual. The study involved men 17 to 43 years of age. The majority was $21-30$ (12 people), $31-40$ (7 people), $18-20$ ( 5 people), 41-50 (2 people), 17 (1 person) years old.

\begin{tabular}{|c|c|c|c|c|}
\hline \multirow{2}{*}{ Age } & \multicolumn{2}{|c|}{ Sexual orientation } & \multirow{2}{*}{ Together } & $\%$ \\
\cline { 2 - 3 } & HOM & HET & 1 & 3,7 \\
\hline up to 18 & 0 & 1 & 5 & 18,52 \\
\hline $18-20$ & 1 & 4 & 12 & 44,44 \\
\hline $21-30$ & 1 & 11 & 6 & 22,22 \\
\hline $31-40$ & 2 & 5 & 2 & 7,41 \\
\hline $41-50$ & 2 & 0 & 0 & 0,00 \\
\hline over 50 & 0 & 0 & 27 & 100 \\
\hline In total & 6 & 21 & & \\
\hline
\end{tabular}

Table 1. Men's age

Source: own research

HOM - men who declared homosexual orientation HET - men who declared heterosexual orientation

Among the respondents, 16 men had secondary education. One man had primary education (Mark, 43). Three men were students (Lucas 23, Krystian 22, Damian 21), two of them were master-degree students (Krystian 22, Lucas 23), and one was a first-degree student (Damian 21). Four men were higher educated (Adam 26, Patrick 29, Hubert 36, Alexy 26). Three young boys were still secondary school students (Christopher 18, Borys 18, Charles, 17), who lived with their parents.. Two men had graduated from high school (Jarek 20, Robert 20) and basic vocational school (Louis 36, Greg 32). Most of them treated the income obtained from prostitution as additional (17 people), while three men were unemployed (Oscar 25, Louis 43, Aleks 23).

Table 2 presents a short characterization of respondents. Each person has been assigned a fictitious name. The alphabetical order is not related to the order of data analysis and did not reflect any hierarchy or evaluation. 


\begin{tabular}{|c|c|c|c|c|c|}
\hline Name & Age & Education & Region of Poland & City population & Marital status \\
\hline Adam & 26 & Higher & eastern & from 20 to 100 thousand residents & single \\
\hline Aleksy & 26 & Higher & north & $\begin{array}{l}\text { from } 100 \text { to } 500 \text { thousand } \\
\text { residents }\end{array}$ & single \\
\hline Arek & 22 & Post-secondary & western & over 500,000 residents & single \\
\hline Borys & 18 & Secondary & eastern central & capital city & single \\
\hline Cyprian & 24 & Secondary & central & over 500,000 residents & single \\
\hline Damian & 21 & Secondary & North & $\begin{array}{l}\text { from } 100 \text { to } 500 \text { thousand } \\
\text { residents }\end{array}$ & single \\
\hline Greg & 32 & Vocational & south & $\begin{array}{l}\text { from } 100 \text { to } 500 \text { thousand } \\
\text { residents }\end{array}$ & single \\
\hline Hubert & 36 & Higher & eastern central & capital city & married \\
\hline Jack & 36 & Secondary & eastern central & capital city & $\begin{array}{l}\text { single/in a partner } \\
\text { relationship }\end{array}$ \\
\hline Jarek & 20 & Middle school & eastern central & from 20 to 100 thousand residents & $\begin{array}{l}\text { single/in a partner } \\
\text { relationship }\end{array}$ \\
\hline Charles & 17 & Secondary & south & over 500,000 residents & single \\
\hline Konrad & 43 & Secondary & middle & over 500,000 residents & single \\
\hline Krystian & 22 & Higher & eastern central & capital city & single \\
\hline Christopher & 18 & Secondary & south & over 500,000 residents & single \\
\hline Louis & 36 & Vocational & eastern central & $\begin{array}{l}\text { from } 100 \text { to } 500 \text { thousand } \\
\text { residents }\end{array}$ & $\begin{array}{l}\text { single/in a partner } \\
\text { relationship }\end{array}$ \\
\hline Lukas & 23 & Higher & eastern central & capital city & $\begin{array}{l}\text { single/in a partner } \\
\text { relationship }\end{array}$ \\
\hline Maciej & 30 & Secondary & western & over 500,000 residents & married \\
\hline Marcin & 33 & secondary & western & from 20 to 100 thousand residents & single \\
\hline Mark & 43 & Elementary & eastern central & from 20 to 100 thousand residents & single \\
\hline Matthew & 19 & Secondary & eastern central & capital city & single \\
\hline Michael & 36 & Secondary & central & over 500,000 residents & $\begin{array}{l}\text { divorced/in a } \\
\text { partners relationship }\end{array}$ \\
\hline Norbert & 36 & Secondary & western & over 500,000 residents & single \\
\hline Oscar & 25 & Secondary & eastern central & od 200 do 500 thousand residents & $\begin{array}{l}\text { single/in a partner } \\
\text { relationship }\end{array}$ \\
\hline Patrick & 29 & Higher & eastern centrale & capital city & single \\
\hline Peter & 30 & Secondary & south & from 20 to 100 thousand residents & married \\
\hline Robert & 20 & \begin{tabular}{|l} 
Lower \\
secondary
\end{tabular} & southeastern & od 100 to 200 tys. residents & single \\
\hline Zenon & 27 & Secondary & eastern central & from 20 to 100 thousand residents & single \\
\hline
\end{tabular}

Table 2. Characteristics of study participants

Source: own study 


\section{ANALYSIS OF RESULTS}

When examining the phenomenon of male prostitution, special attention should be paid to people interested in using these services. The surveyed men were asked about them. What are their requirements? Why do they use this kind of services? Additionally, respondents were asked about their opinion on people using their services. It was one of the most elaborated topics of conversation with respondents and is evidenced by many replies. In general, any inhibitions during the interviews were not observed. The openness and honesty of the respondents were rather characteristic.

Four groups of people using paid sexual services were selected based on respondents' statements. The first group consists mainly of women, mostly married ones as well as in the age range 30 to 45 . Occasionally there were women, both younger than 23 and older, women over 45:

In general, I met women up to 45 . From 30 to 45 , this was an age range. (...) 30-year-old women usually had a home, family, husband and they also just wanted a springboard from everyday life. (Maciej 30)

Mostly people much older. The record is sixty-four, but usually thirty, forty-five. Most of them are married women. (Borys 18)

Women in their forties, probably 43 years old. Two women were 35 years old. (...) For the most part, I saw the ring. Married? Well, there were married women. (Louis 36)

Differently, they were 25 and 45. (...) I can honestly say that married women dominate. Well, this is also a good group in terms of the fact that they are already experienced and solvent women, so they often propose a system on the basis of sponsorship. (Damian 20)

From 23 to 45 . (...) they are married women. Mostly, maintained by the spouse, although there are, of course, independent women, about 40, who have their own company, etc. But it's just, well, they do not tell me that about themselves And yes, they look for good sex. (Peter 30)

Three men emphasize that they avoid meeting with younger women, because it is connected with complications such as exceeding the set limit of emotional engagement. Maciej (30) had similar situations with clients who expected him to divorce:

I was not interested in younger ones, younger women ... because usually, you know how it ended, they fell in love, or wanted me to divorce. Therefore, with the younger ones, I said that I would not meet.

Similarly, Hubert (36) says:

Younger women can fall in love and there is a problem. Although with women aged 40 or so it also happened, (...) however, these women are more, as I would say, realists. 
Arek (22) was surprised that young women are looking for paid sexual partners. He cannot imagine meeting such women:

It is also surprising that for some time I have noticed that younger girls are looking for paid sex partners. What used to be, for example two years ago, unthinkable for a girl who is 19 years old to look for paid sex. I personally would not agree to meet a woman under 26, 27.

Among the clients using paid sexual services, there were also women with different marital status:

Divorced women:

As a rule, they say that they are either divorcees or husband moved out, husband was an alcoholic. (Hubert 36)

A divorcee, some old ladies, whom husbands abandoned. (Adam 26)

Widows:

Or there are many single women because their husbands died. (Hubert 36)

When it comes to the material status of clients, they were usually middle-income or very wealthy women. Here are some examples:

I think that these are mainly women who are unhappy and very rich. They are not middle class, only rich people. (Arek 22)

They were educated women, like some kind of academic teacher around 40, something like that, such medium-wealthy women. (Adam 26)

The second group of people using sexual services are men. In this group of clients, the majority of surveyed men pay attention to the sexual orientation of clients.

Men buying sex are both homosexual and bisexual people, as reported:

Mainly they are gays but also bisexuals, often married. (Christopher 18)

Mostly these were married guys at the age of 50,40, sometimes younger. (Marcin 33)

Clients of escort agencies are men over 30, which Robert reveals (20):

Those who use the agency are aged 30+. I had a client, a very well-known actor, who was 82 years old. But he just wanted me to undress. He looked at me. We laughed, talked and I sat naked, he was wearing clothes, I was naked, and that was enough for him, yes.

Borys (18), points out that he meets men with so-called "necessity":

With men, as I said before, I do not meet more than twice. I do it very rarely i.e. if there are no other orders, or money finishes, then I decide on them. I meet them the least often.

On the other hand, men in the age range 30 to 55 most often use street prostitution: From 40 to 55 years of age. (Marcin 33 \& Marek 43) 
There are clients, they are young like 30 years old. They occupy high positions, they earn really good money. And also over forty. (Zenon 27)

In Berlin, customers were much older says Jack (36):

There, it's different, there gentlemen are even 60 or 70 years old, and they go after sixteen or seventeen year old boys, gypsies like that. I will tell you one thing: they pay well. I never wanted such old ones, I always had those from 20 to 40 and usually went with them to their home or hotel.

When it comes to customers' professional lives, the clients were men running their own business.

Most often they dealt with various things in life and changed their jobs, these were mainly businessmen. (Christopher 18)

Clergymen were also mentioned as clients:

I also had priests as lovers. Listen in Wroclaw I had a sponsor Marcin, who was a priest, listen, rich priest, rich monk, yes. (Marcin 33)

Others were clerks:

Sometimes, either a bank employee or somebody, for example, who is the manager. (Konrad 43)

Clients were also people from the medical industry, the legal industry, as well as from the so-called show business:

Lawyers, doctors, as well as a judges and prosecutors, I had a client, a very wellknown actor, well-known designers. (Robert 20)

Another group of people using paid lovers are couples. Three men met with them. Peter (30) meets men together with their wives, but these sex-meetings take place sporadically. However, he noticed that the demand for the implementation of sexual fantasies like the threesome is more often pursued by men, this is what he says:

A man wants to meet with me more than the wife. The partner forces the woman to do it, because he has some fantasies in a threesome, he wants some things, but doesn't ask his partner what she wants.

Michael (36), in turn, emphasizes that during these meetings he does not have sex with a man:

Couples are 30 and over, and 50, too. I do not meet with the guys themselves, because it does not interest me at all, I did not have a relationship with a guy. I mean, you know, for specific sex, but not for a relationship with men, as I have never been seeing a man, but I have met with couples or with mixed company.

Borys (18) claims that meetings with couples are interesting:

Couples are very cool, open, they care about their acquaintance. Cool people, different than the rest of society. They are not boring and are expressive. (...) With 
pairs it is very interesting, because men usually only look how I do their partners.

The fourth and last group are people after gender change, so-called shemale. Borys (18) also meets such a person. She is his peer:

Shemale is young, my age, we are friends, only that I have sex with her for money and she is not quite a normal girl after sex change, strangely, but tolerably. I like her, she is my peer, so I can talk to her about everything and I think she understands me the most. Maybe because she does not feel very confident in this world herself. I meet her for sex, because it's difficult for her to find a partner who would accept it. And it does not bother me.

Here are some more statements from the surveyed men:

Married women are mainly neglected by their husbands and they have their needs. They usually arrange one-time massages. You know like for 100 PLN... (Lukas 23)

Neglected emotionally. Their husbands are not interested in them, they do not care about their needs, only, you know, he comes home, wants to eat dinner and like this. He does not care about her, he does not take her anywhere, you know, he does not care. He will not even say, you know, "honey, you look good.” Even such a small stupid thing. (Peter23)

Some women also have the opportunity to talk or hug during these meetings. In other words, they buy the closeness of another human being. This is what the other respondents are talking about:

Some also want me to talk to them, they cry on my shoulder, because at home, for example, they are treated badly. They are looking for some approval. They want to talk more about themselves, because, for example, they do not have it at home, because the husband, for example, goes away for business trips, nobody is at home. They are looking for someone who will satisfy them. (Maciej 30)

They were waiting for hugs, they were waiting to talk about more than just cars. Yes, a smart conversation about something that ... they are interested in. (Cyprian 24)

Women also satisfied their need for adoration:

They would like to be adored, and their partner does not even know how many teaspoons of sugar she takes in her tea, right? Such a stupid example. He never brought her a flower, because today is Friday. He never did anything crazy for her, etc. The older ones needed such appreciation more. (Cyprian 24)

Another reason was the unmet sexual needs. What Matthew (19) says:

Because he cannot satisfy her. Fuck I don't know, he cannot get it up or what?

Peter (30) also gives other, specific reasons:

One of them, for example, does not get along with her husband, he has a small 
penis, and she just cannot enjoy sex. The guy is not big enough, not experienced enough, and the woman has no satisfaction.

Life partners are not able to meet the expectations of women, which is also reflected by Patrick (29):

They have a weak sexual partner. Well, in my opinion. And also just want to experience something new.

Krystian (22), The client wanted to experience sexual pleasure:

She just told me she wanted to try. And she said she was fed up with, bluntly saying, weaklings. She wanted someone who can perform, in short, she wanted to have orgasms.

Maciej (30) also talks about it:

You know what, I think they just need good sex.

Damian (20):

Above all, satisfying sexual needs, escaping boredom and routine in bed, they like, so to speak, good fucking.

And also like Peter (30):

But half of them are just sexually unsatisfied. Because they could do it all the time, and the guy can only drink beer, eat chips, and maybe she can encourage him twice a month. This is a different sex drive. Everyone has a different sex drive.

He notices that women buy sex because they like it, but in cultural terms they do not want to be perceived as "easy":

They really like sex, but they do not want to look in their own group as so-called "easy sex" that's why they are looking for discreet people with whom they can experience something new.

Similarly, Aleks (26) also points out that sex is the main reason for using his services:

I think around $70 \%$ buy services because of sex, and 30\%, for good company.

On the other hand, non-heterosexual ${ }^{3}$ clients expect mainly sexual satisfaction, which the surveyed homosexual men pointed out. For example:

They want to satisfy themselves and go home. Blowjob, anal, for men it is mainly about sex. Mainly it's anal and oral sex, this is the most common. (Zenon 27)

Another reason mentioned by the respondents was the treatment of these sex-meetings as a form of fun and entertainment. Cyprian (24) claims that they are usually

\footnotetext{
${ }^{3}$ Non-heterosexual (non-heteronormative) - the term derives from the queer theory of people who do not boil down to sexual heterosexuality. The general concept includes homosexual, bisexual, asexual, transgender and queer people. In the case of my research, they are homosexual men according to their declaration of sexual orientation.
} 
mostly younger women:

The younger ones are more bursting, we go out somewhere together and while having good fun, we make passionate satisfying sex. Then it comes out naturally.

Although, in this form of entertainment, women in the age range of 40-60 are also interested Hubert (36) says:

Most often these women say that they just want to have fun. They just want some fulfillment, they need heat.

Michael (36) says:

I'm just for their company, whether you are naked or dressed, it depends on the situation and the company. Mostly, they want to have fun.

Cyprian (24)points out that some women need company at meetings:

Typically, the social events or going to the cinema, then sex. I travelled all over Poland. These ladies covered the travel costs etc.

But also the man's company was necessary at business meetings:

Sometimes these meetings are integrative, where the owners, directors have to show someone, because it must look good. In the same way, like in the Oscars gala, these ladies and gentlemen come with somebody, it seems to me that this is a standard in business.

Reasons for using sexual services may also be A method of retaliation. Two respondents indicate that although women do not always have evidence of betrayal they intuitively feel that their husbands are cheating on them:

She could sense that her husband was cheating on her while on delegations, so it could also be treated as a retaliation on her husband. (Norbert 36)

Borys (18) says:

It's surprising, but most of them are really hot. They just feel unappreciated or are cheated on. They probably have caught them or just sensed infidelity.

Whereas Oscar (25) declares that his sponsor did not want to have a life partner, but only a sexual partner:

(...) she did not want to have a boyfriend, because she went through it a few times, she just wanted to have a sexual partner. She had a dozen or so from what I remember. She did not say exactly how many.

Borys (18) confirms:

(...) they have quite a lot of men. I am something fresh, untainted, I don't know if it's true, they say so. And I'm good at sex, because I am a long-distance runner. And I'm passionate.

Another reason for using the sex services is the problem in finding a suitable life partner, Robert (20) draws attention to it: 
It's hard to find a partner, (...) gays have a problem with that, right? Because gay has a problem with finding a partner of any kind, whether for sex or for life, because there are not many of them. And here age doesn't matter, even if they are old.

Also men who prefer sexual contacts with young immature boys, have a problem with finding a partner, as Robert points out. For them, the escort agency prepares an offer of this type of services:

A boy, who is very tiny and slim. He looks like such an innocent child, he is 18 years old, but he is more for those pedophiles you know. They find it amusing that he looks like a child. There are not many pedophiles, but for those who want, there is this guy.

Borys (18) mentions another reason - partner's infertility. He offers the fertilization of the female sex clients. In this way, he has made eight women pregnant and explains the course of such a transaction:

Generally, I am very cautious, I do not want to get into alimony and being dragged to the court. I hold back everything for a very long time. Minimum a month of acquaintance. A lot of conversations and questions, then we meet for coffee. She checks her fertile days and we arrange to make sex until the anticipated result.

For fertilization:

I fertilize at the fourth meeting, when the chances for pregnancy are the highest.

First, I make sure that the woman has conditions for raising children, then we write a contract in which everything is concluded.

In the contract:

I waive the rights to the child.

The reason for using sexual services by women is also boredom. Since they have financial resources, they can also buy sex whenever they want, as Damian (21) says:

There are also those who do it out of boredom, they don't know what to do with cash. They want sex, so they buy it, whenever they want it, and if they have this option, they use it.

Such a picture is confirmed by Lukas (23):

If you buy somebody, it is because you want to have no limitations, and want to steam off the way you like it.

He says that if he refuses to fulfill specific desires, he will lose customers:

There are some guys out there who do the same things as you. They are even more handsome. They're bigger, they're better in bed. You are aware that if you refuse something, she will say thank you and find another one.

In sex-business there are also abuses and acts of violence. When the client decides to buy sexual services, they want to fulfill their own fantasies and expectations. They 
usually do not pay attention to the sexual needs of a paid lover, treating them objectively. This is manifested, for example, by humiliation and ordering. That is what Patrick (29) felt:

It happened that they treated me like an object. If he pays, he requires.

After these negative experiences, he avoids clients from whom he might expect negative reactions:

Now I do not even enter into such relationships. If I feel that someone has a predisposition to it, then I immediately break the relation.

He also says that he meets such women:

Well she orders me to be here and there, do this and that (...) She says that she pays and she requires it. There is no equality principle, she considers herself better.

Similar observations are also made by Greg (32):

They think that they have money and can change somebody, because they pay and require (...) They have a lot of requirements. Well, that they think that I am their slave.

Krystian (22) described his client more vulgarly:

It is awkward for me to talk about it, but she was such a bitch.

Although he saw advantages:

Yes, she had charisma, she could talk (...) She was sometimes so cold (...) Sometimes you can tell that they have big money. Looking at some people you can see that they have class (...) something more than just money.. And it's nice talking to them.

Another abuse highlighted by respondents is humiliation and challenge. Arek (22), experienced that with one of the clients:

I am looking for another one, a stable one, but one of these four I would quit. (...) I am not satisfied with her ... hmm... character and I do not like the payment form. And she treats me a little like a rag (...) She swears, she offends me during intercourse (...) He calls me names, a male whore, she shows who's the boss here, because she pays (...) She gets such a great satisfaction from that. I noticed that it turns her on, but not necessarily me.

Mark (43) met with similar behavior by the clients, mainly when he refused to perform some services:

Sometimes I heard that I was a whore.

Another abuse was violating of the contract provisions set out at the beginning:

He wants to do what I do not want to do. There are small conflicts.

Marek (43) also did not always agree to meet the client's expectations: 
Many times it was so that the client does not know what he wants from me. I did not always agree.

He definitely refused the following:

Something with violence, tying, gagging. I never agreed to this, or some group sex, it was out of question. (...) I was afraid of violence.

Although some customers, despite refusing, did not give up:

I said: no, and he did not let go.

In such situations he tried to escape:

I managed to escape once or twice. Those clients had flats on the first and the ground floors. It was not high, I could escape through the window.

Zenon (27) considers abuse cases when the client does not pay for the service provided:

There were such situations that he did not pay for the service (...) I went home with him, I would tell him he should pay that and that much, and he did not pay (...) He said he would pay in the morning, and he did not pay at all, and in the morning he wanted sex , then I said no (...) They usually want the same price for sex, but then I say no, because they have to pay more.

Jack also confirms such situations (36):

Two guys, I do not know if they were a couple or some psychopaths, but they used me and they did not pay me.

He did not receive payment for the service and was sexually abused:

They raped me. They tied me to bed and then raped me a few times, but it was the worst case. So they try to get you drunk and use you or not pay for the service.

However, such situations might even end up dramatically like for his friend. He was abandoned in an unknown and dangerous neighborhood:

They took him to the forest and he was there without clothes, nothing, he was beaten up. After a week, they found him.

Jack is afraid of meetings with clients at their homes:

I can still go to the hotel, but I've always been afraid of going home, and there, from behind the door, two or three might jump out.

Robert (20) presents different faces of clients:

Usually, there are people who order us about (...). Perverted for sure, yes they are very perverted, because no-one normally uses such an agency. (...) I'm talking about other boys who are unfortunately passive and are unfortunately treated differently (...)

He gives the example of a friend who was drunk:

There was one boy one time, who was such a fag, he was hetero, but... One client 
got him so drunk, this guy. He was so wasted so the client knew he could anything with him. So he fucked him and made him passive.

For sexual exploitation the client uses force or deception. They also abuse the boys by forcing them to have an intercourse without a condom. Robert informs us:

Nobody knows if he used the protection or not. Theoretically, he could have infected a boy with a disease.

In addition to the fact that men are victims of physical, emotional and sexual violence on behalf of the clients, they also experience it from other people, eg homophobes:

Mainly by “jocks". They were bothered by the fact that two guys went to bushes, they went there and beat them up. They shouted: "There are two faggots going there, you have to beat them!” There were about two, three or even four of them. They walked with sticks or glass bottles.

Sometimes there are also casualties:

Well, they killed many of them there. You heard that some time ago they killed one boy there. Last year, they attacked them in Skaryszewski [the name of the city park], one of them even cut off their heads and they put them in the pool. Well, the worst is going on in this Skaryszewo.

To sum up, violence is a deliberate abuse of power or authority that violates the rights of respondents. Four types of violence have been reported:

Psychological violence: humiliation, ridicule, calling names, demanding obedience, lack of empathy, imposing one's own opinion and preferences, using threats, etc.

Sexual violence: forcing unacceptable sexual behaviors, failure to keep contracts, forcing intercourse without a condom, sex without paying, sexual abuse, raping, etc.

Physical violence: kicking, incapacitation, bonding, beating, abandonment in a dangerous area, entrapment, homicide, etc.

Economic violence: haggling, no payment for the service (Gardian-Miałkowska 2013: 147).

\section{SUMMARY AND CONCLUSIONS}

In summary, people using sexual services of male prostitutes are women, men, transgender people and couples. The main reasons are unsatisfied sexual needs or partner's infertility or insufficient sexual skills. Some women do not want to be perceived as sexually liberated. Each of these group satisfies more than only their sexual needs. Women usually feel the lack of interest from their partners and they still need to be adored, cuddled and desired. The use of sexual services becomes a way of dealing with 
the deprivation of these needs. Some women treat sex with male prostitutes as a form of retaliation against an unfaithful partner. A large group of clients cannot find a suitable life partner. Some because they have unusual sexual preferences, and others because of gender changes. An additional advantage for clients is spending nice time with fun companion.

These persons, according to the information provided by the respondents, were lonely people, including divorced and widowed; well-off people who occupy high positions or have well-run business. There were also clergymen.

I found that people who use sexual services are:

(1) Women (young, middle-aged and older) mostly married, 28-55 years old;

(2) Men of similar marital status and age like women using paid sex services;

(3) Heterosexual couples - contact with a sex worker was usually initiated by a man who tried to realize his own erotic fantasy (eg controlled betrayal);

(4) People after gender change.

The people using paid sexual services are usually middle-income and wealthy people, although there were people with lower material status. These people represent professions such as are clerks, businessmen, artists etc. It is worth paying attention to women who have adopted male behavioral patterns. Currently, under the influence of social changes, women are much more aware of their sexual needs and are not afraid of talking about them and satisfying them, while such attitudes and behaviors were previously reserved mainly for men.

It was established that both women and men who use sexual services treat prostitutes as objects to satisfy their needs. It was also found that during sex-meetings, both male and female clients use various forms of abuse against men involved in prostitution. Differences can be seen depending on the gender. Women much more often use emotional sexual abuse, violating the established rules of sexual intercourse. However, men use all forms of violence - physical, emotional, sexual and economic violence. Some violate personal rights of male prostitutes. Some respondents mentioned physical violence such as: beating, bonding, incapacitating, entrapment, abandonment in dangerous areas, murder, etc. Some of them reported: humiliating, threatening, lack of empathy, demanding obedience, imposing one's own opinion and preferences, etc. Others spoke about sexual violence, including: sex without payment, failure to keep contracts, enforcing unacceptable sexual preferences, forcing intercourse without a condom, raping, etc. Economic violence was mentioned as not paying for a service or haggling. Although some men experienced various forms of abuse and violence, they did not give up their services. In this way, they obtain financial and material benefits.

It was noticed that the reasons for using paid sexual services were as follows (in terms of their prevalence): 1) unsatisfactory sexual contacts; 2) a sense of loneliness and neglecting by the life partner; 3) partner's infertility; 4) heartbreak or betrayal of a partner; 5) problems with finding the right partner; 6) unusual sexual preferences; 7) change of gender; 8) treatment of sex-meetings as a form of entertainment. 
Male and female clients use the services of male prostitutes depending on their individual needs. Some of them meet each time with someone else, while others occasionally meet with the same man, and still others propose the so-called sponsorship system. They can also pay for the availability of a lover, and some cover the costs of trips. Both male and female clients can be found in various places, such as: discos, clubs, escort agencies for men, streets.. However, the most common is the internet, which offers a wide range of possibilities in choosing a potential sexual partner. A large group of men post photos of their figure and penis, describe their dimensions. Phone or email is only needed when using the information included in the sex-ads.

Undoubtedly, it is worth paying attention to women who have adopted male behavioral patterns. Under the influence of social changes, the role of man and woman have changed and even become similar. Nowadays women are much more aware of their sexual needs and are not afraid to talk about them, much less to satisfy them, while such attitudes and behaviors were previously reserved mainly for men. It was established that both women and men using sexual services treat prostitutes objectively, perceiving them as a tool to meet their needs. It was also established that during sex meetings both clients and clients use various forms of abuse against men involved in prostitution. The differences can be seen by gender. Women are much more likely to use emotional and sporadic sexual violence, violating established rules of sexual intercourse. Whereas men use all forms of violence, because it is both physical, emotional, sexual and economic violence. Relatively little is known about couples and people after sex change. The author does not know the research in this area. It is worth considering this aspect in further research and expanding the state of knowledge in this area. The author's research is a good start.

FUNDING: This research received no external funding.

CONFLICT OF INTEREST: The author declares no conflict of interest.

\section{REFERENCES}

Collins, Andy. 2004. Sekrety seksu. 777 różnic między kobietą a mężczyzną. Warszawa: Oficyna Wydawnicza RYTM.

Gardian-Miałkowska, Renata. 2016. Fenomen męskiej prostytucji w Polsce. Warszawa: Difin.

Gardian-Miałkowska, Renata. 2012. "Sponsorowana prostytucja w środowisku akademickim.” Prace IPSIR 20: 291-304.

Gardian-Miałkowska, Renata. 2013. “(Nie)bezpieczeństwo świadczenia usług seksualnych. Świadomość ryzyka i konsekwencji pracy w sex-biznesie na przykładzie mężczyzn uwikłanych w prostytucję.” Profilaktyka społeczna i resocjalizacja 22: 131-52. 
Hajcak, Frank \& Patricia Garwood. 2001. Dlaczego ze sobq sypiamy. Nieseksulane powody, dla których ludzie uprawiaja seks. Gdańsk: GWP.

Imieliński, Kazimierz. 1990. Manowce seksu. Prostytucja. Łódź: Wydawnictwo RES POLONA.

Kurzępa, Jacek. 2012. Młodzi, piękne i niedrodzy. Młodość w objęciach seksbiznesu. Kraków: Rubikon.

Kurzępa, Jacek, Alicja Lisowska \& Agnieszka Pierzchalska. 2008. Prostytucja "nieletnich" w perspektywie dolnoślazaków. Raport z badan. Wrocław: Falochron.

Marlowe, Julian. 1997. "It's Different for Boys." in Whores and Other Feminists, edited by J. Nagle. New York: Routledge. Retrieved June 30, 2014 (https://www.walnet. org/csis/groups/swav/marlowe-boys.html).

Orliński, Wojciech. 2013. “Gdzie kochają Polki?” Wysokie obcasy 13(363): 38-42.

Pospiszyl, Irena. 2008. Patologie społeczne. Warszawa: Wydawnictwo Naukowe PWN.

Rot, Sylwester. 2009. “Męska prostytucja.” Retrieved June 30, 2014 (http://doza. o2.pl/?s=4097\&t=11570).

Schifter, Jacobo. 1998. Lila's house: Male Prostitution in Latin America. New York, London: Harrington Park Press.

Smith, Michael D. \& Christian Grov. 2011. In the Company of Men. Inside the Lives of Male Prostitutes. Santa Barbara, California, Denver, Colorado, Oxford, England: Praeger.

Śpila, Bożena. 2006. "Zdrowotne i psychologiczne aspekty prostytucji.” Pp. 94-95 in Prostytucja jako problem społeczny, moralny i zdrowotny, edited by M. Jędrzejko, Wydawnictwo Akademii Humanistycznej A. Gieysztora: Pułtusk-Warszawa.

Weitzer, Ronald. 2009. “Sociology of Sex Work.” Annual Review of Sociology 35: 213-34. West, Donald J. \& Buz de Villier. 1993. Male prostitution. London: Duckworth.

\section{BIOGRAPHICAL NOTE}

Renata Gardian-Miałkowska - doctor of social sciences in the field of pedagogy. Assistant professor at the Institute of Social Sciences at the Stefan Batory State University in Skierniewice. Experienced educator with 20 years of practice. Her research interests relate to risky sexual behavior and sexual violence.

OPEN ACCESS: This article is distributed under the terms of the Creative Commons Attribution Non-commercial License (CC BY-NC 4.0) which permits any non-commercial use, and reproduction in any medium, provided the original author(s) and source are credited.

ARTICLE HISTORY: Received 2019-06-29 / Accepted 2021-05-07 